\title{
PENGARUH VIRAL MARKETING DAN BRAND AWARENESS TERHADAP NIAT BELI MEREK KOPI KENANGAN DI KOTA SURABAYA
}

\author{
Venna Melinda Mulyaputri \\ Universitas Negeri Surabaya \\ vennammp27@gmail.com \\ Sanaji \\ Universitas Negeri Surabaya \\ sanaji@unesa.ac.id
}

\begin{abstract}
This study aims to examine the effect of viral marketing and brand awareness on consumer purchase intentions in the context of social media use, especially Instagram as a media marketer between companies and consumers, by providing information about the product. The sample used in this study amounted to 200 samples distributed online using Google Form. Data were analyzed using a simple linear regression method. Research results are the viral marketing and brand awareness variables positively affect buying intentions "Kopi Kenangan". Based on these results, it is recommended for "Kopi Kenangan" to provide exciting content through Instagram social media in the "Kopi Kenangan" brand promotion strategy.
\end{abstract}

Keywords: brand awareness; viral marketing; purchase intention.

\section{PENDAHULUAN}

Berkembangnya internet memengaruhi cara perusahaan memasarkan atau mempromosikan produknya. Mempromosikan suatu produk dengan cara tradisional atau konvensional masih tetap digunakan dan berfungsi hingga saat ini, namun dengan adanya internet saat ini, perusahaan lebih mudah menyebarkan informasi atau promosi pada konsumen dengan cara yang lebih santai dan mudah dipahami oleh konsumen (Sisira, 2011). Menurut hasil riset Kemp (2020), individu yang menggunakan media sosial di Indonesia mencapai 175,4 juta atau berjumlah $64 \%$ dari jumlah total seluruh populasi. Besar populasi, pesatnya pertumbuhan pengguna internet dan telepon telah memengaruhi perekonomian. Satu dari beberapa media sosial yang banyak diakses di Indonesia yakni Instagram merupakan platform untuk membagikan cerita pada orang lain melalui foto dan video dengan berbagai macam fitur yang ada, dari hal personal sampai berbisnis.

Penelitian ini fokus pada Kopi Kenangan coffee shop dengan konsep yang disukai masyarakat yaitu grab and go yang telah menggunakan cara online pada penjualannya yaitu dengan menggunakan serta mengambil manfaat dari media sosial menjadi alat guna menawarkan produknya pada konsumen. Instagram merubah cara berinteraksi konsumen, cara melihat suatu merek yang akibatnya instagram berhasil menarik 40\% merek top dunia (Scissons et al, 2015). Sejak berdiri pada tahun 2017, Kopi Kenangan telah memiliki 80 gerai di 8 kota (Eka, 2019). Menggunakan sistem grab and go yang saat ini digemari oleh masyarakat urban. Instagram dan Facebook merupakan salah satu dari media sosial yang ada di Indonesia. Kopi Kenangan yang telah berdiri sejak tahun 2017 dan pesaingnya Kopi Janji Jiwa yang baru berdiri pada tahun 2018 sama-sama menggunakan viral marketing pada media sosial. Kopi yang paling banyak dipesan yaitu Kopi Janji Jiwa sebesar 23,6\% dan Kopi Kenangan sebesar $14,2 \%$. Sedangkan untuk media sosial instagram Kopi Kenangan memiliki 211.000 pengikut dan Kopi Janji Jiwa memiliki 367.000 pengikut dapat diketahui dari data tersebut bahwa Kopi Janji Jiwa lebih unggul daripada Kopi Kenangan. Mengapa Kopi Kenangan yang terjun lebih awal bisa dikalahkan oleh Kopi Janji Jiwa yang sama menggunakan strategi viral marketing dan brand awareness sebagai alat komunikasi pemasaran (Cahya, 2019).

Saat ini viral marketing menjadi strategi pemasaran yang digunakan untuk media sosial (Akyol, 2013). Perusahaan sangat tergantung oleh internet dan media sosial, orang akan melakukan berniat pembelian melalui media sosial saat ini (Hinz et.al., 2011). Viral marketing dan brand awareness 
Venna Melinda Mulyaputri \& Sanaji. Pengaruh Viral Marketing dan Brand Awareness terhadap Niat Beli Merek Kopi Kenangan di Kota Surabaya

sangat efektif dan efisien untuk pemasaran saat ini yang bertujuan memberikan stimulus bagi konsumen untuk melakukan keputusan pembelian pada suatu produk. Sebagai hasilnya viral marketing pada internet akan menyebarluaskan berita atau informasi secara cepat dan luas (Ellison dan Boyd, 2013).

Dalam sebuah penelitian terdahulu mengatakan bahwa viral marketing pada media sosial instagram @ makananjember berpengaruh signifikan pada niat beli (Kaloka, 2016). Temuan lain juga menunjukkan bahwa viral marketing berpengaruh positif pada niat beli dengan cara memberikan konten yang ofensif atau menarik (Liu dan Wang, 2019). Viral marketing juga berhasil pada kampanye "Let's say thank you" 1,5 juta pesan dikirim pada situs web perusahaan (Klopper, 2012). Penelitian pada pisau cukur Gillete membuahkan hasil di mana lebih dari $20 \%$ konsumen adalah dari viral marketing (Ellison dan Boyd, 2013).

Viral marketing menghasilkan penyebaran informasi sesuai kebutuhan konsumen dari satu akun ke akun lainnya dari hal tersebut selain mempromosikan produk, viral marketing juga bermanfaat untuk menunjang suatu merek (Barichello dan Oliveira, 2010 ). Menurut Ukpebor dan Ipogah (2008) brand awareness bisa meningkatkan tingkat konsumsi konsumen karena meningkatkan keakraban antara merek dan konsumen yang diukur menggunakan pengakuan merek, pengingatan kembali merek dan ingatan pertama konsumen terhadap sebuah merek. Kebiasaan atau gaya hidup masyarakat urban dengan coffee shop menjadi hal yang harus diperhatikan, karena masyarakat urban saat ini menjadi sangat pemilih tentang adanya coffee shop di wilayah mereka untuk dijadikan tempat nongkrong (Henz, 2018). Namun masyarakat urban tidak membeli apa yang sesungguhnya mereka butuhkan melainkan untuk membeli simbol atau tanda yang ditawarkan kepada masyarakat urban tentang apa yang seharusnya dibeli (Ritzel, 2003:139). Kotler dan Armstrong (2016) mengatakan bahwa pemasaran secara online adalah pemasaran secara cepat, untuk meberikan informasi yang dibutuhkan konsumen melalui alat yaitu internet dan media sosial. Pemasaran online adalah upaya perusahaan guna menjual produk serta jasa dan juga menjalin ikatan dengan konsumen menggunakan internet. Alternatif dalam menjalankan promosi online menggunakan media sosial adalah instagram. Penelitian ini bertujuan untuk mengetahui adanya pengaruh viral marketing dan brand awareness terhadap niat beli Kopi Kenangan Kota Surabaya.

\section{KAJIAN PUSTAKA DAN PENGEMBANGAN HIPOTESIS}

\section{Viral Marketing}

Menurut Hasan (2010), viral marketing merupakan cara penyebaran informasi yang memiliki tujuan untuk mempromosikan suatu produk melalui mulut ke mulut dengan menggunakan internet yang di mana informasi akan mudah disebarkan dari satu orang ke orang lain seperti virus. Menurut Camarero \& San Jose (2011) viral marketing adalah penyebaran pesan atau informasi yang dilakukan oleh individu secara suka rela membagikan pada kontak mereka atau tidak. Dalam proses ini, semakin banyak individu yang menerima pesan maka akan semakin memengaruhi individu tersebut untuk menyebarkan kembali pesan tersebut kepada individu lainnya.

Terdapat dua jenis viral marketing, yaitu organic viral marketing dan amplified viral marketing. Organic viral marketing yaitu promosi pemasaran yang tidak terkontrol, yang menyebar di antara orang-orang (word of mouth) tanpa bantuan pemasar. Tren ini menggunakan biaya yang rendah yang secara dramatis dapat meningkatkan kesadaran merek, karena berasal dari komunikasi konsumen Adapun, amplified viral marketing adalah kampanye pemasaran yang direncanakan secara strategis, yang dapat dikendalikan oleh pemasar melalui penelusuran hasil (Stokes, 2012). Elemen viral marketing menurut Wilson (2012) dalam Lekhanya (2014:216) yaitu memberikan produk dan layanan, mudah transfer ke orang lain, skalabilitas dari kecil ke yang sangat besar, eksploitasi motivasi dan berilaku, manfaatkan sumber lain, memanfaatkan internet sebagai alat komunikasi.

Adapun dua faktor pendukung variabel viral marketing yaitu konsumen dan buzz. Konsumen yang mempunyai internet dan mempunyai hubungan dengan orang lainnya dalam hubungan interpersonal. Menurut Wiludjeng (2013), indikator viral marketing terdiri dari tiga hal yakni pengetahuan produk, 
pejelasan informasi, dan membicarakan produk. Viral marketing melalui Instagram dapat dilakukan dengan memanfaatkan fitur-fitur yang telah disediakan oleh Instagram. Advertiser menyampaikan pesan iklan di instagram melalui buzzer yang telah dipilih. Berdasarkan pendapat para ahli di atas viral marketing adalah strategi pemasaran yang digunakan untuk tujuan menstimulus orang yang melihat untuk menyebarkan pesan tersebut ke orang lain mulai dari kalangan sosial teman secara nyata maupun teman di media sosial.

\section{Brand Awareness}

Brand awareness (kesadaran merek) adalah kemampuan identifikasi seorang konsumen pada sebuah merek di kondisi yang berbeda, sekaligus bisa terjadi dengan pengenalan merek serta pengingatan kembali/ memorize pada sebuah merek atau brand (Radder dan Huang 2008). Kesadaran merek (brand awareness) memiliki peranan penting untuk jalannya perusahaan, konsumen cenderung memilih dan membeli merek yang telah diketahui. Brand awareness menggambarkan seberapa jauh merek tersebut di benak konsumen (Andrologi, 2014). Menurut Hermawan (2014:57), kesadaran merek merupakan sejauh mana seseorang untuk mengenal, mengetahui dan mengingat merek dari suatu produk yang ada. Tingkatan brand awareness terdiri atas unaware of brand unware of brand (tidak sadar akan brand) yakni potensi yang terendah, di mana konsumen tidak mengenal sama sekali brand tersebut. Tingkatan ini adalah tingkatan yang hendaknya dihindari oleh perusahaan. Brand recognition (pengenalan brand) merupakan kesadaran pada merek diambang bawah atau minimal, di mana konsumen akan mengingat suatu merek ketika dilakukan pengingatan kembali dengan bantuan pada merek yang disebutkan. Pada tahap ini konsumen mampu mengidentifikasi merek tetapi melalui usaha peninjauan kembali. Brand recall (pengingatan kembali brand) merupakan tingatan middle pada brand awareness karena konsumen mampu mengingat suatu merek dengan mengingat kembali tanpa bantuan atau stimulus. Serta yang paling utama adalah top of mind (puncak pikiran) ingatan pertama dalam benak sesorang ketika merek disebutkan.

Pengukuran brand awareness menurut (Aaker dalam Durianto, 2004) dengan Top of Mind (Puncak pikiran yang paling diingat oleh konsumen). Brand recall (pengingatan kembali suatu merek), brand recognition (pengenalan merek setelah diberi bantuan), juga unaware of brand (tak sadar akan suatu merek). Dari beberapa pendapat ahli di atas dapat dilihat bahwa brand awareness merupakan sebuah tolok ukur sejauh apa konsumen mengetahui merek suatu produk.

\section{Niat Beli}

Menurut Kotler (2016:200), niat beli merupakan tindakan konsumen dalam memikirkan suatu produk yang ingin dimiliki dan berdasar atas pengetahuan tentang merek tertentu. Sehingga niat merupakan suatu kecenderungan melakukan suatu tindakan untuk segera merealisasikan kegiatan pembelian yang sebenarnya. Penelitian yang dilakukan oleh (McClelland, 2016) untuk mengukur niat beli menggunakan beberapa indikator yaitu find information abouth the product (mencari informasi tentang produk), consider buying the product (mempertimbangkan untuk membeli produk), serta intending to purchase (berniat membeli produk). Berdasarkan teori serta artikel yang telah ditemukan, maka guna mengukur variabel promosi niat beli menggunakan indikator dari McClelland (2016) dan Raharjo \& Sugiharto (2013) yang telah disesuaikan dengan objek penelitian.

\section{Hubungan Antar Variabel}

Berdasarkan Hasan (2010:42), viral marketing merupakan kegiatan mempromosikan suatu produk dari mulut ke mulut melalui media internet dan media sosial yang juga dikenal sebagai $e$-word of mouth marketing yang bertujuan seperti menyebaran virus, informasi akan mudah disebarkan dengan cepat dan luas oleh seseorang yang melihatnya. Penelitian terdahulu oleh Liu dan Wang (2019) menyatakan bahwa viral marketing berpengaruh positif terhadap niat beli. Penelitian oleh Shara Nuraini viral marketing pada Garlick Store membangun kepercayaan dan niat beli pada konsumen. Penelitian lain mengatakan bahwa viral marketing berpengaruh dalam niat beli (Vianna, 2016).

H1: Variabel viral marketing berpengaruh positif terhadap niat beli Kopi Kenangan Surabaya. 
Venna Melinda Mulyaputri \& Sanaji. Pengaruh Viral Marketing dan Brand Awareness terhadap Niat Beli Merek Kopi Kenangan di Kota Surabaya

Menurut Hermawan (2014:57), kesadaran merek merupakan sejauh mana seseorang untuk mengenal, mengetahui dan mengingat merek dari suatu produk yang ada. Hubungan kesadaran merek, preferensi merek dan niat beli ulang menunjukkan bukan hanya niat pembelian tetapi juga untuk membangun emosional merek dan pasar konsumen (Sanaji, 2015). Penelitian lain menunjukkan bahwa konten yang dibuat perusahaan memengaruhi kesadaran merek melalui media online dan juga berpengaruh pada niat pembelian secara offline (Dabbous, 2020). Kesadaran merek berpengaruh secara tidak langsung dengan niat beli konsumen (Mehrullah, 2018).

Menurut penelitian Katja Hutter (2013), brand awareness berpengaruh signifikan terhadap niat beli. Penelitian Ghafoor (2013) menunjukkan siginifikansi antara brand awareness, brand loyalty pada niat pembelian. Sanaji (2015) juga menemukan bahwa brand awareness berhubungan positif dengan niat beli. Hubungan antar variable juga dapat dilihat d Gambar 1.

H2: Variabel brand awareness berpengaruh positif terhadap niat beli Kopi Kenangan Surabaya.

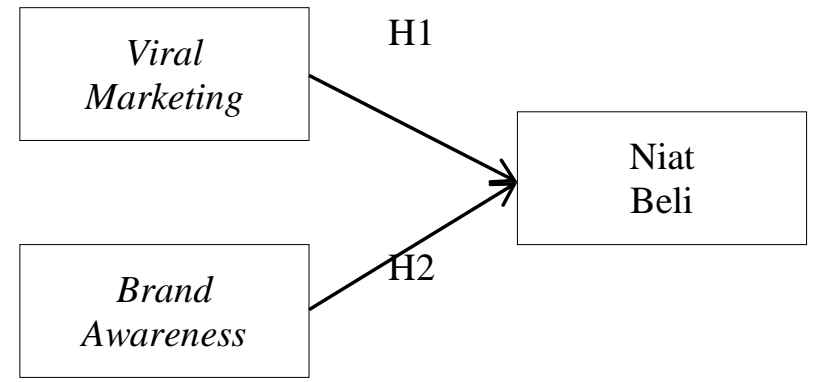

Gambar 1. KERANGKA KONSEPTUAL

\section{METODE PENELITIAN}

Populasi dalam penelitian ini merupakan warga kota Surabaya yang merupakan pengguna aplikasi sosial media Instagram. Responden yang digunakan dalam penelitian ini memiliki karakteristik berusia 17- >40 tahun. Pengambilan sampel yang digunakan dalam penelitian ini menggunakan teknik non-probability sampling dengan metode judgement sampling. Terdapat 200 responden yang diperoleh dalam pengambilan data. Pengukuran penelitian ini menggunakan skala likert untuk variabel viral marketing dan niat beli sedangkan untuk variabel brand awareness menggunakan teknik pengukuran dengan tiga item pertanyaan yang merujuk (Kim dan Kim, 2005). Indikator yang digunakan guna mengukur pada variabel pertama viral marketing (X1) menurut Sri Wiludjeng SP dan Tresna Siti Nurlela (2013:54) yaitu (1) affection-alturism (2) curiosity (3) content consumption (4) content forwading. Brand awareness diukur merujuk (Kim dan Kim, 2005) dengan (1) top of mind (2) brand recall (3) brand recognition. Item pertanyaan 1 "Tulislah satu merek minuman kopi kekinian yang paling anda ingat" guna mengukur top of mind. Item pertanyaan 2 "Selain merek tersebut sebutkan 3 merek yang paling anda ingat" guna mengukur brand recall. Untuk item pertanyaan 3, responden diminta agar melakukan pemilihan pada merek yang tidak mereka ketahui. Dalam hal ini terdapat 5 merek kopi yang di identifikasi yaitu, Jokopi, Kopi Janji Jiwa, Kopi Kulo, Kopi Lain Hati, dan Katalokopi. Jawaban tiga item pertanyaan itu kemudian akan dikonvers, dengan skala 1 sampai dengan 7 poin merujuk (Kim \& Kim, 2005). Merek yang telah dipilih di pernyataan ketiga diberikan nilai 1, yang artinya kurang sadar akan brand tersebut (Unaware). Apabila merek tak disebut dalam pertanyaan 1,2, dan 3, maka diberikan skor 2. Artinya memiliki kesadaran akan brand tersebut (Brand Recognize) ataupun mampu mengingatnya dengan bantuan. Merek yang disebut pada pertanyaan 2, sesuai urutan dari atas, diberikan nilai 4, 5 juga 6 . Artinya pengingatan kembali sebuah brand (Brand Recall). Merek yang disebut pada pertanyaan 1 diberikan nilai 7 adalah puncak pemikiran brand (Top of Mind).

Variabel niat beli diukur merujuk Mclelland (2016) yang terdiri dari (1) tertarik guna mencari informasi (2) mempertimbangkan guna melakukan pembelian (3) tertarik guna membeli (4) berniat untuk membeli. Penyebaran kuesioner ini menggunakan media online dengan menggunakan google 
form. Teknik analisis pada penelitian ini adalah regresi linier berganda dengan menggunakan uji asumsi klasik yakni uji normalitas, uji multikolinieritas dan uji heterokedastisitas. Kemudian data akan diproses dengan uji hipotesis dengan menggunakan uji t.

\section{HASIL DAN PEMBAHASAN}

\section{Uji Validitas dan Reliabilitas}

Hasil uji validitas dan reliabilitas pada penelitian ini dinyatakan dan reliabel. Dinyatakan valid karena nilai correlated item total atau $\mathrm{r}$ hitung $>\mathrm{r}$ tabel dan bernilai positif sedangkan dikatakan reliabel karena nilai cronbach's alpha $>0,70$. Adapun hasil uji validitas dan reliabilitas dapat dilihat pada tabel 1.

Tabel 1.

HASIL UJI VALIDITAS DAN RELIABILITAS

\begin{tabular}{llcc}
\hline Variabel & \multicolumn{1}{c}{ Pertanyaan } & $\begin{array}{c}\text { Corelated } \\
\text { Item Total }\end{array}$ & $\begin{array}{c}\text { Cronbach's } \\
\text { Alpha }\end{array}$ \\
\hline Viral Marketing & Adanya hubungan antara Kopi Kenangan dan konsumen pada & 0,841 & \\
& media sosial Instagram & 0,828 & \\
& $\begin{array}{l}\text { Saya ingin tahu bagaimana konten instagram Kopi Kenangan } \\
\text { Saya memiliki insensitas tinggi dalam mengakses account }\end{array}$ & 0,904 & 0,886 \\
& instagram Kopi Kenangan & & \\
& Saya Menyampaikan informasi tentang produk Kopi Kenangan & 0,887 & \\
Niat Beli & kepada konsumen media sosial instagram & 0,831 & \\
& Saya tertarik untuk mencari informasi tentang Kopi Kenangan & 0,795 & 0,863 \\
& Saya mempertimbangkan untuk membeli Kopi Kenangan & 0,89 & \\
\hline & Saya tertarik untuk membeli produk di Kopi Kenangan & 0,862 & \\
\hline
\end{tabular}

Sumber: Data diolah (2020)

\section{Hasil Uji Asumsi Klasik}

Sebelum dilakukan uji regresi linier, peneliti melakukan uji asumsi klasik yang terdiri dari uji normalitas dengan nilai signifikansi 0,017 , uji multikolinearitas dengan nilai VIF 1,063, uji heterokedasitas dengan nilai signifikansi variabel brand awareness sebesar 0,967 dan variabel viral marketing sebesar 0,231. Berdasarkan hasil uji asumsi klasik tersebut maka data penelitian dapat dikatakan normal serta tidak terjadi gejala multikolineritas dan heterokedasitas sehingga layak untuk digunakan dalam uji selanjutnya. Uji kelayakan model sebesar $24,5 \%$ yang menunjukkan bahwa kontribusi model untuk hubungan struktural variabel brand awareness dan viral marketing terhadap niat beli adalah sebesar $24,5 \%$ dan $75,5 \%$ lainnya dijelaskan oleh variabel lain yang tidak termasuk dalam model penelitian.

\section{Karakteristik Responden}

Setelah melakukan uji asumsi klasik serta dikatakan mampu memenuhi syarat penelitian, maka selanjutnya dilakukan pengujian statistik deskriptif yang digunakan untuk mengetahui karakteristik responden dalam penelitian. Karakteristik responden dalam penelitian ini dapat dilihat pada tabel 2.

Dari hasil yang telah dipaparkan dapat dilihat bahwa dari 200 responden yang telah mengisi kuesioner jenis kelamin yang mendominasi ialah perempuan yaitu sebesar $65 \%$ atau sebanyak 130 responden. Sedangkan usia menunjukkan bahwa usia 17-22 tahun sangat mendominasi dalam penelitian Kopi Kenangan. Profil pekerjaan pelajar atau mahasiswa mendominasi yaitu sebanyak $71 \%$ atau 143 responden.

\section{Deskripsi Variabel Viral Marketing dan Niat Beli}

Berdasarkan hasil pengolahan data terhadap variabel viral marketing dan niat beli maka terdapat nilai rata-rata yaitu untuk variabel viral marketing 3,66 dengan std. deviation 1,039 sedangkan untuk 
Venna Melinda Mulyaputri \& Sanaji. Pengaruh Viral Marketing dan Brand Awareness terhadap Niat Beli Merek Kopi Kenangan di Kota Surabaya

variabel niat beli sebesar 3,85 dengan std. deviation sebesar 0,941 . Rata-rata tertinggi adalah variabel niat beli.

\section{Tabel 2. \\ KARAKTERISTIK RESPONDEN}

\begin{tabular}{llcc}
\hline & Karakteristik & Frekuensi & Persentase (\%) \\
\hline Jenis Kelamin & Laki-laki & 70 & $35 \%$ \\
& Perempuan & 130 & $65 \%$ \\
Usia & 17 - 22 Tahun & 150 & $75 \%$ \\
& 23 - 28 Tahun & 46 & $23 \%$ \\
& 29 - 34 Tahun & 4 & $2 \%$ \\
\multirow{5}{*}{ Pekerjaan } & 36 - 40 Tahun & 0 & $0 \%$ \\
& $>40$ Tahun & 0 & $0 \%$ \\
& Pelajar/ Mahasiswa & 143 & $71 \%$ \\
& Karyawan Swasta & 44 & $22 \%$ \\
& Pegawai Negeri & 0 & $0 \%$ \\
& Wirausaha & 0 & $0 \%$ \\
& Lain-lain & 13 & $7 \%$ \\
\hline
\end{tabular}

Sumber: Data diolah (2020)

Tabel 3.

HASIL UJI REGRESI

\begin{tabular}{lccc}
\hline \multicolumn{1}{c}{ Variabel } & Koefisien Regresi & $\mathbf{t}_{\text {hitung }}$ & Sig. \\
\hline (Constant) & 2,141 & 9,636 & 0,000 \\
Brand_awareness & 0,084 & 3,150 & 0,002 \\
Viral_marketing & 0,367 & 6,357 & 0,000 \\
\hline
\end{tabular}

Sumber: Data diolah (2020)

\section{Hasil Uji Regresi}

Hasil uji regresi dilihat dari nilai hasil uji parsial (uji t). Hasil uji parsial (uji t) dalam penelitian ini dapat dilihat pada tabel 3.

\section{Uji Hipotesis}

Pengujian hipotesis menggunakan uji t parsial pada toleransi kesalahan (alpha) sebesar 5\%. Hasil pengujian hipotesis secara parsial dengan cara membandingkan signifikansi $t_{\text {hitung }}<$ alpha. Suatu variabel bebas dikatakan berpengaruh terhadap variabel terikat apabila nilai signifikansi $t_{\text {hitung }}<0,05$. Variabel viral marketing nilai $\mathrm{t}_{\text {hitung }}$ sebesar 6,183 dengan signifikansi $0,002<0,05$, sehingga dapat dinyatakan bahwa variabel viral marketing berpengaruh terhadap variabel niat beli (Y) di Kopi Kenangan. Variabel brand awareness nilai $t_{\text {hitung }}$ sebesar 3,424 dengan signifikansi $=0,000<0,05$, sehingga variabel brand awareness berpengaruh terhadap variabel niat beli di Kopi Kenangan.

Pada tabel 3, dapat dilihat bahwa nilai sig. Sebesar 0,000, artinya brand awareness dan viral marketing bepengaruh secara simultan terhadap niat beli. Karena jika sig $<0,05$ maka hipotesis diterima. Berdasarkan hasil output SPSS, dapat dilihat di mana nilai $\mathrm{F}$ hitung lebih besar dari pada nilai $\mathrm{F}$ tabel $(31,915>3,04)$ dengan tingkat signifikan di bawah 0,05 yaitu 0,000 . Berdasarkan cara pengambilan keputusan uji simultan dalam analisis regresi menunjukkan variabel viral marketing dan variabel brand awareness signifikan terhadap niat beli kopi kenangan. Hasil uji kelayakan model pada penelitian ini menunjukkan bahwa $24,5 \%$ faktor dipengaruhi oleh brand awareness dan viral marketing sedang $75,5 \%$ lainnya dipengaruhi oleh faktor lain. 


\section{Pengaruh Viral Marketing terhadap Niat Beli}

Hasil penelitian ini menunjukkan adanya pengaruh viral marketing terhadap niat beli, artinya semakin menarik konten viral marketing yang dilakukan oleh sebuah merek maka akan meningkatkan pula niat beli konsumen terhadap merek tersebut. Hasil penelitian ini mendukung penelitian dari Liu \& Wang (2019), Nuraini dan Vianna (2016) menyatakan hasil bahwa viral marketing berpengaruh positif terhadap niat beli. Viral marketing ini erat kaitanya dengan pemasaran melalui mulut ke mulut versi internet di mana konsumen satu merekomendasikan ke konsumen lainnya dengan melihat atau mendengar informasi produk Kopi Kenangan melalui media sosial. Viral marketing yang dilakukan oleh Kopi Kenangan pada Instagram ialah mengunggah konten yang menarik pada akun instagram milik Kopi Kenangan yang berisi informasi produk, promo produk, games dan interaksi dengan konsumen pada instagram. Pada penelitian ini variabel viral marketing diukur dengan menggunakan 4 indikator yakni: adanya hubungan antara Kopi Kenangan dan konsumen pada media sosial instagram, bagaimana konten instagram kopi Kenangan, insensitas tinggi dalam mengakses account instagram Kopi Kenangan, menyampaikan informasi tentang produk Kopi Kenangan kepada konsumen lainnya di dalam media sosial.

\section{Pengaruh Brand Awareness terhadap Niat Beli}

Selanjutnya juga terdapat pengaruh positif dalam pengaruh brand awareness terhadap niat beli. Sehingga semakin tinggi tingkat awareness terhadap suatu merek atau brand maka akan semakin tinggi atau semakin meningkatkan niat beli terhadap merek atau brand tersebut. Hasil penelitian ini mendukung penelitian dari Hutter (2013) dan Ghafoor (2013) yang menyatakan hasil bahwa variabel brand awareness berpengaruh positif terhadap niat beli. Dalam hasil penelitian ini, tingkat awareness masyarakat terhadap merek Kopi Kenangan berada pada tingkat brand recall. Namun secara keseluruhan meski berada pasa tingkat brand recall, hal ini masih tetap berpengaruh terhadap niat beli pada merek Kopi Kenangan. Niat beli masyarakat di era ini lebih mudah terstimulus dengan adanya internet dan media sosial. Hal tersebut terjadi karena generasi milenial saat ini cenderung menyukai hal yang instan, cepat dan mudah diakses untuk mendukung mobilitas yang tinggi. Selain didukung oleh viral marketing sangat bermanfaat untuk meningkatkan daya tarik seseorang terhadap merek Kopi Kenangan, hal tersebut juga menjadikan kesadaran merek masyarakat terhadap Kopi Kenangan semakin menaingkat. Karena dengan adanya viral marketing yang digunakan oleh perusahaan untuk promosi akan mudah diakses dengan mudah dan cepat.

Selanjutnya untuk variabel brand awareness berpengaruh signifikan positif pada niat beli tetapi memiliki dampak lebih kecil daripada viral marketing terhadap niat beli sesuai hasil penelitian. Hal tersebut dikarenakan viral marketing lebih mestimulus tingkat ketertarikan konsumen. Namun demikian brand awareness tetap menunjang niat beli konsumen sesuai dengan penelitian sebelumnya di mana konsumen akan membeli sebuah produk sesuai dengan pemahaman akan suatu merek (Zarlish Shahid, 2017). Dengan hal itu maka viral marketing dan brand awareness sangat berguna untuk menunjang niat beli dengan menggunakan media sosial menjadi alat guna melaksanakan promosi penjualan, melalui inovasi dan konten yang berkualitas konsumen akan tertarik dengan produk.

\section{KESIMPULAN}

Penelitian ini membuktikan pengaruh positif viral marketing terhadap niat beli pada Kopi Kenangan dan terdapat pengaruh positif brand awareness terhadap niat pembelian. Terdapat implikasi teoritis pada penelitian ini yaitu bahwa variabel viral marketing, dan brand awareness berpengaruh positif pada niat beli produk. Selain itu implikasi bagi perusahaan atau pemasar adalah untuk memperhatikan konten viral marketing yang dapat meningkatkan daya tarik konsumen untuk melakukan pembelian. Selain itu, berdasarkan hasil penelitian, responden didominasi oleh responden dengan usia 17-22 tahun dan berprofesi sebagai pelajar/ mahasiswa sehingga perusahaan atau pemasar dapat memfokusikan promosi pasar terhadap karakteristik tersebut. Penelitian ini tidak terlepas dari banyak keterbatasan, situasi pandemi covid-19 mengakibatkan pelaksanaan penelitian tidak berjalan secara maksimal. Pengambilan data hanya dilakukan secara online sehingga data yang diperoleh kurang 
Venna Melinda Mulyaputri \& Sanaji. Pengaruh Viral Marketing dan Brand Awareness terhadap Niat Beli Merek Kopi Kenangan di Kota Surabaya

bervariasi dan hanya didominasi oleh responden dengan rentang usia 17-22 tahun dan berprofesi sebagai pelajar/ mahasiswa.

Berdasarkan hasil penelitian, tingkat kesadaran konsumen terhadap merek Kopi Kenangan berada pada tingkat brand recall, satu level lebih rendah dari tingkat top of mind sehingga disarankan bagi pemasar agar selalu memperhatikan beberapa strategi yang dapat meningkatkan tingkat kesadaran tersebut. Hal ini dapat ditunjang dengan lebih baik lagi serta memberikan konten yang menarik lewat media sosial instagram dalam strategi promosi merek "Kopi Kenangan". Penilitian selanjutnya dapat melibatkan brand ambassador, influencer, social media serta beberapa variabel lain yang menjadi pendorong niat beli konsumen terhadap suatu merek. Peneliti selanjutnya juga dapat meneliti merek kopi kekinian lain yang menjadi top of mind di benak konsumen.

\section{DAFTAR PUSTAKA}

Akyol, Ş. (2013). Social Media and Marketing: Viral Marketing. Academic Journal of Interdisciplinary Studies, 2(8), 586-590. https://doi.org/10.5901/ajis.2013.v2n8p586

Andrologi, F. (2014). Analisis Pengaruh Brand Image dan Brand Awareness Terhadap Brand Loyalty dan Dampaknya Terhadap Brand Equity. Universitas Diponogoro.

Ali, H. (2010). Marketing. Yogyakarta: Media Presindo.

Andini, N. (2014). Pengaruh Viral Marketing Terhadap Kepercayaan Pelanggan Dan Keputusan Pembelian (Studi Pada Mahasiswa Fakultas Ilmu Administrasi Universitas Brawijaya Angkatan 2013 yang Melakukan Pembelian Online Melalui Media Sosial Instagram). Jurnal Administrasi Bisnis S1 Universitas Brawijaya, 11(1), 82726.

Cahya, P. (2019). Meramal Usia Kopi Susu Kekinian: Hanya Tren atau Panjang Umur Betulan? Retrieved March 7, 2020, from https://www.idntimes.com/food/dining-guide/putrianacahya/tren-kopi-susu-kekinian/11

Camarero, C., \& San José, R. (2011). Social and attitudinal determinants of viral marketing dynamics. Computers in Human Behavior, 27(6), 2292-2300. https://doi.org/10.1016/j.chb.2011.07.008

Dabbous, A., \& Barakat, K. A. (2020). Bridging the online offline gap: Assessing the impact of brands' social network content quality on brand awareness and purchase intention. Journal of $\begin{array}{lllll}\text { Retailing and Consumer Services, } & 01966 .\end{array}$ https://doi.org/10.1016/j.jretconser.2019.101966

Durianto, D. (2004). Strategi Menaklukkan Pasar: Melalui Riset Ekuitas dan Perilaku Merek. Jakarta. Gramedia Pustaka Utama.

Durianto, D., Sugianto, \& Budiman, L. J. (2004). Brand Equity Ten Strategi Memimpin Pasar. Jakarta: Gramedia Pustaka Utama.

Eka, R. (2019). Kopi Kenangan Umumkan Perolehan Pendanaan 282 Miliar Rupiah dari Sequoia India. Retrieved from https://dailysocial.id/post/pendanaan-kopi-kenangan-dari-sequoia-india. Diakses pada 12 november 2019

Ellison, N. B., \& Boyd, D. M. (2013). Introduction. Sociality Through Social Network Sites, August 2018, 152-172. https://doi.org/10.1093/oxfordhb/9780199589074.013.0008

Federal, U., \& Maria, D. S. (2010). O marketing viral como estratégia publicitária nas novas ambiências midiáticas. Em Questão, 16(1), 29-44. https://doi.org/10.19132/1808-5245161. 
Ferdinan, A. (2006). Metode Penelitian Manajemen: Pedoman Penelitian Untuk Penulisan Skripsi, Tesis, dan Disertasi Ilmu Manajemen. Semarang: Badan Penerbit Universitas Diponegoro.

Hamilton, V. N. (2018). Determining Millennial Food Buying Preferences: Based On Product Marketing With “Buzzwords.” 1-79. https://doi.org/10.13023/ETD.2018.053

Have, C. ten, Sternthal, B., Craig, C. S., Pescher, C., Reichhart, P., Spann, M., Perera, I., Dharmadasa, P., Zhang, Y., Fan, X., Qian, Y., Huang, P., Paquette, H., Elbers, J., Hegner, M., Fenko, A., Marc, G., Charles, S., Jacobs, S., Boleto, A. R. S. (2013). An in Depth Study of Viral Marketing for the Purpose of Creating a Guide of Best Practices by Aizhan Maulen. Journal of Advertising, 5(1), 34-52. https://doi.org/10.9734/bjemt/2014/9947

Helm, S. (2010). Viral Marketing - Establishing Customer Relationships by ' Word-of-mouse' Viral Marketing - Establishing Customer Relationships by ' Word- Marketing: The User As A. Electronic Markets, December 2013, 37-41. https://doi.org/10.1080/10196780050177053

Hens, H. (2018). Maraknya Kedai Kopi di Indonesia, Bakal Bertahan Lama atau Sekadar Tren? https://www.liputan6.com/lifestyle/read/3727952/maraknya-kedai-kopi-di-indonesia-bakalbertahan-lama-atau-sekadar-tren. Diakses pada 10 November 2019

Hepler, M. A., \& Riechel, T. L. (1981). Identification of the oxidation product of a binuclear mixedvalence vanadium(IV,V) 8-quinolinol complex. Inorganica Chimica Acta, 54(C), 167-171. https://doi.org/10.1016/S0020-1693(00)95452-5

Hermawan, K., \& Setiawan, I. (2014). Wow Marketing. Jakarta: PT Gramedia Pustaka Utama.

Hinz, O., Skiera, B., Barrot, C., \& Becker, J. (2011). Social Contagion-An Empirical Comparison of Seeding Strategies for Viral Marketing. 75(6), 55-71.

Hutter, K., Hautz, J., Dennhardt, S., \& Füller, J. (2013). The impact of user interactions in social media on brand awareness and purchase intention: The case of MINI on Facebook. Journal of Product and Brand Management, 22(5), 342-351. https://doi.org/10.1108/JPBM-05-2013-0299

Kemp, S. (2020). Digital 2020: Indonesia. Retrieved from https://datareportal.com/reports/digital2020-indonesia. diakses pada 8 maret 2020 pukul 14.00

Klopper, H. B. (2002). Viral marketing: a powerful, but dangerous marketing tool. SA Journal of Information Management, 4(2). https://doi.org/10.4102/sajim.v4i2.159

Kotler, Philip, \& Keller, K. L. (2016). Marketing Management (Edisi 15). England: Pearson Education Limited.

Larson, R. J. (2009). The Rise of Viral Marketing through the New Media of Social Media. Faculty Publications and Presentations, 6. http://digitalcommons.liberty.edu/cgi/viewcontent.cgi?article=1009\&amp;context=busi_fac_pu bs

Liu, H.-H., \& Wang, Y.-N. (2019). Interrelationships between Viral Marketing and Purchase Intention via Customer-Based Brand Equity. Journal of Business and Management Sciences, 7(2), 72 83. https://doi.org/10.12691/jbms-7-2-3

Malhotra, N. K. (2009). Riset Pemasaran Pendekatan Terapan.Jakarta. PT Indeks.

Matute, J., Polo-Redondo, Y., \& Utrillas, A. (2016). The influence of EWOM characteristics on online repurchase intention. Online Information Review, 40(7), 1090-1110. 
Venna Melinda Mulyaputri \& Sanaji. Pengaruh Viral Marketing dan Brand Awareness terhadap Niat Beli Merek Kopi Kenangan di Kota Surabaya

https://doi.org/10.1108/oir-11-2015-0373

McClelland, \& Wongweeranonchai, P. (2016). The Influence of Perceived Celebrity Endorser Credibility in Advertising on Purchase Intention of Thai Consumers. Journal of Communication and Innovation, 3(2), 115-136.

Mehrullah, J., \& Rohail, K. (2018). The Impact Of Consumer Interaction On Social Media On Brand Awareness And Purchase I Ntention! Case Study Of Samsung". Journal of Marketing and Logistics, 1(August 2018), 114-129.

Nicol, D., \& Agam, L. A. (2016). The Impact Of Viral Marketing Through Instagram. Proceedings of Bangkok Annual Business and Social Science Research Conference 2016, December, 3-4. https://doi.org/10.1210/en.139.7.3088

Petruzzellis, L., \& Winner, R. S. (2016). Rediscovering The Essentially of Marketing (Springer (ed.)).Switzerland: Springer International Publishing

Pomalaa, L., Mursityo, Y. T., \& Herlambang, A. D. (2018). Analisis Faktor Brand awareness, Brand Exposure, Customer Engagement, Dan Electronic Word-of-Mouth Dalam Pemasaran Melalui Media Sosial Pada The Body Shop Indonesia. Jurnal Pengembangan Teknologi Informasi Dan Ilmu Komputer (J-PTIIK) Universitas Brawijaya, 2(10), 4082-4091.

Press, P. D. I., Kim, H., \& Gon, W. (2005). The Relationship Between Brand Equity and Firm Performance in Luxury Hotel and Chain Restaurant, tourism management, Journal of Brand Management vol.26, 549-560.

Ristania, N., \& Justianto, J. S. (2015). Analisa Pengaruh Harga, Promosi, dan Viral Marketing Terhadap Keputusan Pembelian Pada Online Shop S-Nexian Melalui Facebook. Journal of Business Strategy and Execution, 5(2), 131-161.

Riyanto, A. D. (2020). Hootsuite (We are Social): Indonesian Digital Report 2020. Retrieved from https://andi.link/hootsuite-we-are-social-indonesian-digital-report-2020/. Diakses pada 8 Maret 2020

Sanaji. (2015). Eksplorasi Dampak Komunitas Merek Online Di Media Sosial Terhadap Konsistensi Hubungan Konsumen Dengan Merek. Jurnal Riset Ekonomi Dan Manajemen, 15(2), 382-395. https://doi.org/10.17970/jrem.15.1502015.ID

Schiffman, L., \& Kanuk, L. L. (2000). Perilaku Konsumen (B. Sarwiji (ed.); Sevent Edi). Jakarta: Indeks.

Scissons, M. (2015). Instagram Marketing Strategy. Toronto: FlashStock Technology Inc.

Sha, R. (2019). Ini 5 Jenis Kopi Favorit yang Paling Sering Dipesan Milenials. Retrieved from www.idntimes.com website: https://www.idntimes.com/food/dining-guide/rella-sha/ini-5-jeniskopi-favorit-yang-paling-sering-dipesan-milenials-c1c2/1. Diakses pada 12 Desember 2019

Shahid, Z., Hussain, T., \& Zafar, F. (2017). The Impact of Brand Awareness on the Consumers' Purchase Intention. Journal of Accounting \& Marketing, 06(01), 1-4. https://doi.org/10.4172/2168-9601.1000223

Sharma, R., \& Sharma, S. K. (2015). An Emperical Research on Influence of Viral Marketing on Consumers Buying Dicisions. International Journal Of Marketing, Financial Services \& Management Research, 4(5), 171-186. 
Sindo, W. (2019). Indonesia Digital 2019: Media Sosial - Websindo. Www.Websindo.Com. https://websindo.com/indonesia-digital-2019-media-sosial/. Diakses pada 7 Desember 2019

Sisira, N. (2011). Social Media and Its Role in Marketing. International Journal of Enterprise and Business Systems. International Journal of Enterprise Computing and Business Systems, 1(2), $1-15(230-8849)$.

Social, W. A. (2019). Berapa Pengguna media sosial di Indonesia. https://databoks.katadata.co.id/. Diakses pada 7 Desember 2019

Sugiyono. (2017). Metode Penelitian Pendidikan (Pendekatan Kuantitatif, Kualitatif dan $R \& D)$.Bandung: CV. Alfabeta.

Wiludjeng, S., \& Nurlela, T. S. (2013). Pengaruh Viral Marketing Terhadap Keputusan Pembelian Pada PT" X". Proceeding Seminar Nasional dan Call of Paper Sancall. 978-979. Retrieved from http://publikasiilmiah.ums.ac.id:8080/handle/123456789/3838. 